ence of National and University Libraries seminar on Human Aspects of Library Instruction held at the University of Reading on December 9, 1969, are available for purchase from the Secretary of the Conference, The Library, University College, P.O. Box 78, Cardiff, England, at a price of 10 shillings.

- The 1970 annual Serials Holdings List of the UCLA Biomedical Library has recently been printed. This computer-generated publication includes information on over 12,000 ceased as well as current titles, complete holdings statements, call numbers, history notes, and shelving locations of 6,495 current unbound titles. A limited number of copies of the List are available for purchase at $\$ 5.00$ each. Purchase requests should be addressed to: Mrs. Nancy Brault, Serials Librarian, UCLA Biomedical Library, Center for the Health Sciences, Los Angeles, California 90024. All requests must be accompanied by a check for $\$ 5.00$ made out to Regents of the University of California.

- The Union List of Scientific and Technical Serials in the University of Michigan Library,

APPOINTMENTS

Arden Alpaugh has accepted a position as reference librarian at Southern Alberta Institute of Technology, Calgary, Alberta, Canada.

Mrs. Suzette Bell has been named assistant librarian, the School of Library Service library, Columbia University.

Mrs. Sandra Betr has joined the catalog service of the Northern Arizona University library, Flagstaff.

JOANNE H. BOELKE has been appointed reference librarian, Northwestern University library, Evanston, Illinois.

JoHN P. BuzAs is now assistant catalog librarian at the University of Illinois library, Chicago Circle.

Mrs. Menle L. Canfield has been appointed to the position of assistant cataloger, with the rank of instructor, at Oklahoma State University library, Stillwater.

Dr. Johs H. M. Chen has been named associate librarian and head of the Pennsylvania State University's Capitol Campus library, University Park.

Thomas A. Childers is joining the faculty of the Graduate School of Library Science, Drexel University, Philadelphia, as assistant professor.

Cecilta Ching-Chu Lo has assumed the duties of catalog librarian, Northern Arizona University, Flagstaff.

JoHN W. CHuRch has been appointed curator of photographic archives and assistant pro-
5 th edition, is now available. It includes more than 23,000 titles drawn from the holdings of twenty-three of the libraries in the University of Michigan library system. Each title entry gives the official main entry, library location, holdings, and call number. Some 5,500 crossreferences have also been provided to assist users. All new entries and corrections submitted to the editorial staff through March 15, 1970, have been included. The fifth edition may be purchased for $\$ 10.00$ from Business Services Division, Technical Services Department, University Library, The University of Michigan, Ann Arbor, Michigan 48104.

- The first edition of the Rochester Regional Research Library Council's Union List of Serials has been published by the Council. The list contains 12,798 titles representing the holdings of thirty area academic and special libraries. It does not include either the Rochester Public Library or the University of Rochester's holdings, which will be included in the second edition. The list is available from the Rochester Regional Research Library Council, Room 525, Hall of Justice, Rochester, New York 14614. Price $\$ 50.00$ per copy.

\section{Personnel}

fessor of photography, University of Louisville library, Kentucky.

Dan O. Clemmer, JR., has been appointed to the position of assistant to the director of libraries, Smithsonian Institution libraries, Washington, D.C.

Geongia R. Coffin has been appointed associate librarian and chief catalog librarian, Pennsylvania State University library, University Park

Ruth K. Collien is now administrative assistant in the Medical Information Service Center at the Medical Library, University of Virginia, Charlottesville.

Martin Colverd has been appointed assistant to the associate director of technical services, Columbia University library.

Richami W. Cruce has assumed the position of assistant reference librarian at the University of Illlnois library, Chicago Circle.

James M. Deay has assumed the position of head of acquisitions service, Northern Arizona University, Flagstaff.

Marilyn DeGeus is now the head librarian of the college library, Kansas City College of Osteopathy and Surgery.

Mrs. Cynthia D. Dobson is joining the Iowa State University library staff, Ames, as instructor.

Richard Dougherty is joining the faculty of the Syracuse University School of Library Science, Syracuse, New York. 
RUdOlPH ElLENBOGEN has been appointed assistant librarian of the college library, Columbia University.

Marilyn Elves is cataloger for the social sciences section, Cameron Library, University of Alberta, Edmonton, Alberta, Canada.

James E. Falt has been named head of the processing department, Columbia University library.

JoHN FELBINGER received appointment to a cataloging position, Columbia University library.

WILLIAM T. FORD is now serials cataloger in the catalog department, Northwestern University library, Evanston, Illinois.

Mrs. Marta G. Franco has been appointed as an instructor, serving as serials librarian, at York College library, Flushing, New York.

Eltzabeth Frisz has been appointed science librarian, Idaho State University library, Pocatello.

Richard K. Gardner has been appointed director of the ecole de bibliothêconomie, Universite de Montreal, Quebec, Canada.

Mrs. Esther F. Geller has been appointed catalog librarian, Hofstra University library, Hempstead, New York.

MARIE Gosebrink has been appointed assistant director of libraries for Undergraduate Library Services, University of Washington libraries, Seattle.

Mrs. Linda Griffin has joined the staff of the University of Kansas libraries, Lawrence, as assistant cataloging librarian.

Carol Lynda Hall is now a member of the Medical Library staff at the University of Saskatchewan, Saskatoon, Saskatchewan, Canada.

Carlotta Harvey is now with the reference section of the Medical Library, University of Waterloo, Waterloo, Ontario, Canada.

Mrs. Jean C. Hawks is now head serial librarian, Northern Arizona University, Flagstaff.

Mrs. Fay Jackson Henderson has been appointed assistant cataloger, Shepherd College, Shepherdstown, West Virginia.

TONI M. Henderson has been appointed head of the mechanization department and junior instructor at the Medical Library, University of Virginia, Charlottesville.

MrS. JUDith HERSChMAN was appointed Burgess-Carpenter librarian, Columbia University library.

Mrs. Deborah H. R. Huang is joining the catalog department, Northwestern University library, Evanston, Illinois.

LeE HubBard has been appointed to the position of map librarian, University of Washington libraries, Seattle.

ELdON L. Jones is the new assistant librarian, circulation department, Columbia University library.

Mrs. Eugene M. Jones is joining the library staff, Oklahoma State University library, Stillwater, as assistant cataloger.
Mrs. ETHel Kates has been promoted to assistant head catalog librarian of the Hofstra University library, Hempstead, New York.

EDWARD G. Kehde III has been appointed as acting assistant regional history librarian at the University of Kansas, Lawrence.

ErLe P. Kemp has been promoted to associate director for technical services, Columbia University library.

Mrs. Bhigitye L. Kenney is joining the faculty of the graduate school of library science, Drexel University, Philadelphia, as assistant professor.

Mrs. LORNa LeE Kent has been appointed reference librarian, instructor in library administration, University of Oregon, Eugene.

KeNNETH L. KNAPP is now in the search department, Northwestern University library, Evanston, Illinois.

Edith G. KNePper has been appointed interim director of libraries at the University of Louisville, Louisville, Kentucky.

JEAnNE Kocsis is joining the reference staff, University of Massachusetts library, Amherst.

Mrs. Myrla Koendenink has accepted a position in technical services at the University of Calgary library, Calgary, Alberta, Canada.

Gregory Koster has assumed a position in serials cataloging, Columbia University library.

YUK-YING KWAN has been appointed assistant acquisitions librarian, State University of New York, Stony Brook library, Long Island.

RoBert S. LAMB II is the head of the circulation department, Cunningham Memorial library, Indiana State University, Terre Haute.

CHIK-Fong LeE has assumed the position of Chinese cataloger in the Far Eastern library, University of Washington libraries, Seattle.

Mrs. Margaret S. Le Sourd has been appointed assistant documents reference librarian, Pennsylvania State University library, University Park.

JANET LOwSLEY has joined the original cataloging department, Elizabeth Defoe Library, University of Manitoba, Winnipeg, Manitoba, Canada.

Kathleen M. McAdam received appointment as social science librarian, instructor in library administration, University of Oregon, Eugene.

JANE MCCABE has assumed the position of chemistry librarian, Columbia University library.

Mrs. Elizabeth MCCorkle is joining the staff of the Oklahoma State University library, Stillwater, as fine arts and media librarian.

Mrs. Valerie McDougall has been appointed to the staff of the Maxwell Macodrum Library, Carleton University, Ottawa, Ontario, Canada.

Jean McInTyre has been named documents librarian, Idaho State University library, Pocatello. 
Gail Anne McShane is assistant catalog librarian at the University of Illinois library, Chicago Circle.

Mrs. Lucienne G. Maillete was appointed as an instructor, serving as audiovisual and curriculum material librarian, York College library, CUNY.

Joseph MARConi has been appointed head of the social science department, Syracuse University libraries, Syracuse, New York.

ALFRed Di Marrno has been named assistant librarian, Circulation Department, Columbia University.

Gladys Markoff-Sotomayer is now LatinAmerican cataloger, Columbia University library.

Olive Meining has accepted a reference position, Northern Arizona University, Flagstaff.

Pauline F. Micciche has assumed the position of serials librarian charged with the design of a serials program at the State University of New York, Stony Brook library, Long Island.

Virginta Neilsen is now a member of the technical services department at the Harriet Irving Library, University of New Brunswick, Fredericton, New Brunswick, Canada.

Mrs. Helen S. Nordberg has assumed the position of cataloger, Smithsonian Institution libraries, Washington, D.C.

Mrs. Glorta Novak is now a bibliographer in the acquisitions department, Cameron Library, University of Alberta, Edmonton, Alberta, Canada.

LeRoy D. Ortopan has been appointed head of the catalog department, University of California, Berkeley, general library.

Ann F. Painter is joining the faculty of Drexel University, Philadelphia, as associate professor in the graduate school of library science.

Leland M. Park has been promoted to assistant director of the Davidson College library, Davidson, North Carolina.

Albert M. Perdue has been appointed instructor and social sciences bibliographer, Iowa State University library, Ames.

Mrs. Judy Perdue is joining the Iowa State University library staff, Ames, as instructor and cataloger.

Mrs. GaIl Persky has been appointed Slavic cataloger, Columbia University library.

George I. Pike is joining the Oklahoma State University library staff, Stillwater, as social sciences librarian.

Mrs. Ann M. Pogany has been appointed catalog librarian, Kresge Library, Oakland University, Rochester, Michigan.

Mrs. Cynthia Preibish has been appointed to the staff of the reference department, Syracuse University libraries, Syracuse, New York.

Elsa RESNICK is joining the reference staff, University of Massachusetts library, Amherst.
Mrs. Katherine Anne Richahdson is joining the Iowa State University library staff, Ames, as instructor and serials librarian.

Mrs. Glenora Edwards Rosselx has been appointed director of the University of Pittsburgh libraries.

Mrs. Eleanon Sanders has accepted a position as assistant cataloger, Kansas City College of Osteopathy and Surgery library.

EDWARD A. SCOTT has joined the faculty at Winthrop College, Rock Hill, South Carolina, where he will be teaching library science.

Linda E. Seckelson is the newly appointed poetry collection librarian, Northwestern University library, Evanston, Illinois.

Violet Shatzko is cataloger of Slavic language books at the Cameron Library, University of Alberta, Edmonton, Alberta, Canada.

Thomas J. Snyder is now an assistant reference librarian at the Brooklyn Center library of Long Island University.

KAROL Sokol has assumed the position of assistant reference librarian in the law library, Columbia University.

Charles L. Stahl has returned to Northern Arizona University library, Flagstaff, as a reference librarian.

Ruth A. Steele has been named assistant librarian at Pennsylvania State's Beaver Campus in Monaca.

Mrs. Margaret Swanson is in readers' services, Medical Library, University of Alberta, Edmonton, Alberta, Canada.

RICHARD TALBOT is now associate director for technical services, University of Massachusetts library, Amherst.

Norma TaniguchI has been appointed to the technical services staff, Harriet Irving Library, University of New Brunswick, Fredericton, New Brunswick, Canada.

Charles E. Thomas has been appointed instructor and cataloger, Iowa State University library, Ames.

Mrs. Susan Thompson is joining the reference staff, University of Massachusetts library, Amherst.

Chin Tieh-peng is now senior librarian assigned to the catalog department, Cunningham Memorial Library, Indiana State University, Terre Haute.

Mrs. Shirley Ting has joined the staff of the Kansas City College of Osteopathy and Surgery library as cataloger.

Mrs. Alice Vestal has been appointed manuscripts processor in the George Arents Research Library at Syracuse University, Syracuse, New York.

Walter W. Walker is now director, Medical Information Service Center, and assistant professor at the Medical Library, University of Virginia, Charlottesville.

Mrs. Suzanne Ward has joined the University of Louisville library staff as part-time refer- 
ence librarian and instructor in library science, Louisville, Kentucky.

JoYce C. WERner is now associate reference librarian at the University of Illinois library, Chicago Circle.

R. MAx WiLlocks has been appointed assistant director in charge of supporting services and personnel, Syracuse University libraries, Syracuse, New York.

BRuce Worden is cataloger of history and political science at the Cameron Library, University of Alberta, Edmonton, Alberta, Canada.

\section{RETIREMENTS}

- Marianne von Dobeneck, head of the binding department at the Columbia University libraries and a member of the Columbia library staff for thirty-six years, retired June 30 , 1970. In 1966 she was a recipient of the Library Binding Institute's Silver Book Award, presented in recognition of the inaugurating of a book conservation program at Columbia which has become a prototype for programs for other large library systems.

ACRL Membership

August 31,1970

11,714

August 31, 1969

13,238

Äugust 31, 1968

\title{
LENDING LIBRARY of
}

FILMS

\section{SLIDES}

TAPES

PHOTOS

RECORDS

EXHIBITS

FILMSTRIPS

SCIENTIFIC FILMS

On FRANCE

\author{
Catalogue upon request \\ F. A. C. S. E. A.
}

972 5th Avenue, New York City 10021 (2I2)RE 7-9700

\section{Classified Advertising}

\section{NOTICE}

Respondents to advertisers offering faculty "rank" and "status" are advised that these terms are ambiguous and should inquire as to benefits involved.

All advertisements submitted by institutions offering positions must include a salary range. The range should provide the applicant with an indication of the salary the institution is willing to provide for the position offered.

All advertisements for the Positions Wanted and the Positions Open classifications will be edited to exclude direct or indirect references to race, creed, color, age, and sex as conditions of employment.

Classified advertising orders and copy, and cancellations, should be addressed to the Advertising Department, 50 East Huron Street, Chicago 60611, and should reach that office before the tenth of the month preceding publication of issue desired. Copy received after that time may be held for the next issue.

Rate for classified advertising is $\$ 1.25$ per printed line. No additional charge is made for nonmember advertising.

\section{FOR SALE}

CHINESE (Mainly), JAPANESE, KOREAN Collection of books in Western Lang. All Topics. Over 500 vols. Write M. Frazin, 570 Ocean Ave., Brooklyn, N.Y. 11226.

BEILSTEIN'S HANDBUCH der Organischen Chemie, 4.Aufl., Berlin Springer, 1918-1940, 31 V. IN. 33/Also Supps. 1-3,65 V., IN. 74, 1928,1969 completely bound. Price on request. Write: Gifts and Exchange Librarian, Purclue University Libraries, Lafayette, Indiana 47907.

GOVERNMENT PUBLICATIONS mailed to you within 3 days. SuDocs price plus postage. Capital Documents Service, Box 4922, Washington 20008.

\section{POSITIONS WANTED}

A.B. HARVARD, MLS Simmons, MA Berkeley, Ed. D. Buffalo; I9 years library research, editorial teaching, administrative experience; position as Director, college or university library, possibly combined with teaching English or Education. Box 793, CRL, 50 East Huron St., Chicago, Illinois 60611.

LIBRARIAN, 38, accredited MLS, MA in Religion. ACADEMIC EXPERIENCE (3 yrs): UN/US Documents, Social Science/Humanities, 